\title{
PENDEKATAN KONTEKSTUAL MELALUI METODE DEMONSTRASI DAN SIMULASI DALAM PEMBELAJARAN IPA DITINJAU DARI KECERDASAN SPASIAL DAN INTERAKSI SOSIAL SISWA
}

\author{
Yety Purnawirawanti ${ }^{1}$, Sarwanto $^{2}$, Sugiyarto $^{3}$ \\ ${ }^{1}$ Guru di MI Awaliyah Kedungharjo Mantingan \\ Ngawi, 63257, Indonesia \\ purnawirawantiyety@gmail.com \\ ${ }^{2}$ Program Studi Pendidikan Sains PascasarjanaUniversitas Sebelas Maret \\ Surakarta, 57126, Indonesia \\ sar1to@yahoo.com \\ ${ }^{3}$ Program Studi Biosains Pascasarjana Universitas Sebelas Maret \\ Surakarta, 57126, Indonesia \\ sugiyarto_ys@yahoo.com
}

\begin{abstract}
Abstrak
Tujuan penelitian ini adalah untuk mengetahui pengaruh pendekatan kontekstual demonstrasi dan simulasi, kecerdasan spasial dan interaksi sosial siswa serta interaksinya terhadap prestasi belajar. Penelitian ini merupakan penelitian eksperimen, dilaksanakan dari bulan Oktober-November 2012. Populasi penelitian ini adalahsiswa kelas V Madrasah Ibtidaiyah di Kecamatan Mantingan tahun pelajaran 2012/2013 terdiri dari enam madrasah. Sampel diperoleh dengan teknik Cluster random sampling terpilih dua madrasah. Kelas eksperimen I adalah MIN Pakah diberi pembelajaran dengan metode demonstrasi dan kelas eksperimen II adalah MI Awaliyah Kedungharjo diberi pembelajaran dengan metode simulasi. Data dikumpulkan dengan metode tes untuk prestasi belajar kognitif dan data kecerdasan spasial, angket untuk data interaksi sosial, lembar observasi dan angket tanggapan siswa untuk data prestasi belajar afektif dan psikomotorik. Hipotesis diuji menggunakan anava tiga jalan, uji lanjut dengan metode scheffe. Desain faktorial 2x2x2. Dari hasil analisis data disimpulkan: 1). pendekatan kontekstual melalui metode demonstrasi dan simulasi berpengaruh terhadap prestasi belajar, metode simulasi berpengaruh lebih efektif daripada metode demonstrasi; (2). kecerdasan spasial berpengaruh terhadap prestasi belajar; 3). interaksi sosial siswa berpengaruh terhadap prestasi belajar afektif dan psikomotorik; 4). terdapat pengaruh interaksi antara metode dengan kecerdasan spasial terhadap prestasi belajar psikomotorik; 5). terdapat pengaruh interaksi antara metode dengan interaksi sosial siswa terhadap prestasi belajar kognitif; (6). terdapat pengaruh interaksi antara kecerdasan spasial dan interaksi sosial siswa terhadap prestasi belajar afektif; (7). terdapat pengaruh interaksi antara metode, kecerdasan spasial, dan interaksi sosial siswa terhadap prestasi belajar psikomotorik.
\end{abstract}

Kata Kunci:Demonstrasi, simulasi, kecerdasan spasial, interaksi sosial.

\section{Pendahuluan}

Merujuk pada tujuan pembelajaran IPA dalam Pedoman Penyusunan Kurikulum Tingkat Satuan Pendidikan (KTSP) Sekolah Dasar tahun 2008 yaitu: mengembangkan pengetahuan dan pemahaman konsep-konsep dasar IPA yang bermanfaat dan dapat diterapkan dalam kehidupan sehari-hari, serta memperoleh bekal pengetahuan dan konsep konsep serta keterampilan IPA sebagai dasar untuk melanjutkan pendidikan ke jenjang selanjutnya yaitu SMP/MTs. Banyak kendala yang dihadapi dalam upaya untuk mewujudkan tujuan pembelajaran tersebut diatas. Kendala tersebut menyangkut banyak faktor 
diantaranya berkaitan dengan sarana dan prasarana, tenaga pendidik, pengelolaan, maupun kebijakan pendidikan khususnya pada lembaga madrasah.

Kehidupan masyarakat semakin kompleks sehingga kebutuhannya tentang pendidikan dan tuntutan serta ekspektasinya terhadap madrasah juga semakin tinggi, dahulu mungkin mereka "hanya" mengharapkan madrasah dapat memenuhi kebutuhan pendidikan agama anakanak mereka, untuk diamalkan serta menjadi pembimbing dalam kehidupan sehari-hari. Sekarang ini, masyarakat menaruh harapan besar terhadap madrasah. Tidak hanya pendidikan agama Islam yang mereka harapkan dari madrasah, tetapi juga pendidikan umum.

Untuk menjawab harapan besar masyarakat terhadap madrasah, maka setiap guru harus memiliki kompetensi paedagogik dalam menciptakan suasana belajar yang menyenangkan, memotivasi, dan menimbulkan semangat belajar siswa ketika kegiatan belajar mengajar berlangsung. Untuk menciptakan suasana ini diperlukan pengetahuan dan keterampilan yang dimiliki guru dalam rangka memotivasi siswa serta mengaktifkan seluruh potensi siswa dalam menerima pesan pembelajaran yang disampaikan. Salah satu cara efektif dalam menciptakan suasana belajar yang "tidak kaku" namun efektif adalah dengan penggunaan metode pembelajaran yang tepat.

Penggunaan metode pembelajaran yang tepat tidak terlepas dari karakteristik materi pembelajaran yang disampaikan, dan perlu memperhatikan karakteristik mata pelajaran. Materi pembelajaran sistem peredaran darah manusia memiliki karakteristik yang penting, namun sulit untuk dipahami siswa, karena alatalat peredaran darah manusia walaupun bersifat konkret dan dapat dirasakan, namun tidak mungkin untuk dipelajari secara langsung karena dapat membahayakan diri.

Dengan karakteristik materi tersebut dan ditambah dengan kondisi madrasah yang sarana dan prasarana belajar kurang mendukung, serta letak madrasah pada wilayah pedesaan maka penerapan metode pembelajaran yang masih bersifat konvensional cenderung membuat siswa pasif, bosan, mengantuk, malas belajar, dan malas mengerjakan tugas. Guru secara aktif menjelaskan materi pelajaran, kemudian contoh soal dan memberi soal-soal latihan. Interaksi pembelajaran yang muncul hanyalah interaksi satu arah yaitu pengetahuan hanya pada yang disampaikan guru. Padahal banyak penelitian pendidikan yang menyatakan bahwa metode-metode pembelajaran yang baru menghasilkan prestasi belajar IPA lebih baik secara signifikan daripada metode-metode yang lama.

Menurut Piaget dalam Suparno (2006), perkembangan kognitif individu meliputi empat tahap, yaitu; a). tahap sensori-motor (0-2 tahun); b). tahap pra-operasional (2-7 tahun); c). tahap pemikiran operasional konkret (7-11 tahun); dan d). tahap operasional formal (11 tahun ke atas). Dalam perkembangan itu pemikiran anak berkembang pelan-pelan mulai dari sensori-motor, lalu ke pemikiran konkret, dan baru pemikiran abstrak.

Pembelajaran IPA di SD/MI menghendaki siswa memiliki pengetahuan tentang IPA sebagai produk, dan proses. Siswa hendaknya menggunakan kemampuan berpikir untuk mendapatkan konsep IPA melalui serangkaian langkah pembelajaran. Mereka menyusun konsep-konsep berdasarkan langkah-langkah metode ilmiah. Tentu saja terhadap siswa sekolah dasar belum diajarkan cara menyusun sebuah penelitian secara lengkap atau sempurna, tetapi dikenalkan kepada siswa SD/MI secara kompensional, sederhana dan bertahap. Melalui dua dimensi tersebut diatas IPA dapat mengembangkan peserta didik secara menyeluruh dan utuh karena dalam kegiatan IPA melibatkan semua aspek yaitu: emosional, intelektual, dan psikomotor sehingga dapat mencapai prestasi belajar siswa meliputi: kognitif, afektif, dan psikomotor.

Dengan pendekatan kontekstual proses pembelajaran diharapkan berlangsung alamiah dalam bentuk kegiatan siswa untuk belajar mengalami secara langsung, bukan transfer pengetahuan dari guru ke siswa, namun melalui proses pengetahuan dapat disusun siswa secara alamiah. Pengetahuan akan dikonstruksikan siswa antara pengetahuan yang telah dimiliki siswa dengan tema yang dipelajari.

Menurut Trianto (2007), pembelajaran kontekstual didefinisikan sebagai konsep mengajar dan belajar yang membantu guru menghubungkan isi pelajaran dengan situasi dunia nyata. Pembelajaran kontekstual merupakan proses pembelajaran inovatif yang 
membantu siswa menghubungkan isi pelajaran dengan konteks kehidupan. Pembelajaran kontekstual menantang siswa untuk menghubungkan konsep akademik dengan kehidupan sehari-hari dan merangsang siswa untuk berpikir kritis yang membuat pelajaran menjadi efektif dan bertahan lama.

Kontekstual merupakan pendekatan belajar yang membantu guru mengaitkan antara materi yang diajarkannya dengan situasi dunia nyata siswa dan mendorong siswa membuat hubungan antara pengetahuan yang dimilikinya dengan penerapannya dalam kehidupan mereka sehari-hari. Menurut Elaine (2011), CTL suatu sistem yang menyeluruh. CTL terdiri dari bagian-bagian yang saling terhubung. Jika bagian-bagian ini terjalin satu sama lain, maka akan menghasilkan pengaruh yang melebihi yang diberikan bagianbagiannya secara terpisah. Menurut Trianto (2007), pendekatan kontekstual memiliki tujuh komponen utama, yaitu: konstruktivisme (constructivism), inkuiri (inquiry), bertanya (questioning), masyarakat belajar (learning community), pemodelan (modelling), dan penilaian autentik (authentic assessment).

Metode demonstrasi adalah cara penyajian pelajaran dengan memperagakan atau mempertunjukkan kepada siswa suatu proses, situasi, atau benda tertentu yang sedang dipelajari, baik sebenarnya ataupun tiruan, yang sering disertai penjelasan lisan. Dengan metode ini siswa mendapat gambaran secara langsung apa yang dipelajari, walaupun tidak semua siswa dapat mencoba di kelas. Suparno (2006), pembelajaran demonstrasi diartikan sebagai metode mengajar dengan pendekatan visual agar siswa dapat mengamati proses, informasi, peristiwa, alat dalam pelajaran fisika, dengan tujuan siswa lebih memahami bahan yang diajarkan lewat suatu kenyataan yang dapat diamati.

Mulyasa (2011), agar pembelajaran menggunakan metode demonstrasi berlangsung secara efektif, langkah-langkah yang dianjurkan adalah sebagai berikut; a) melakukan perencanaan yang matang sebelum pembelajaran dimulai; b) merumuskan tujuan pembelajaran dengan metode demonstrasi; c) membuat garis besar langkah-langkah metode demonstrasi; d) menetapkan kegiatan demonstrasi tersebut akan dilakukan guru atau oleh peserta didik; e) memulai demonstrasi dengan menarik perhatian seluruh peserta didik; f) mengupayakan agar semua siswa terlibat secara aktif dalam kegiatan pembelajaran; g) melakukan eveluasi terhadap pembelajaran yang telah dilaksanakan.

Tujuan penggunaan metode demonstrasi antara lain: 1). siswa mampu memahami tentang cara mengatur atau menyusun sesuatu; 2). siswa dapat menyaksikan kerja suatu alat atau benda; 3). siswa dapat mengamati bagianbagian dari suatu benda atau alat; 4). bila siswa melakukan sendiri demonstrasi, maka ia dapat mengerti juga penggunaan suatu alat.

Kegunaan metode demonstrasi dalam kegiatan belajar mengajar adalah: 1). dapat membuat pengajaran menjadi lebih jelas dan lebih konkret, sehingga menghindari verbalisme; 2). siswa lebih mudah memahami apa yang dipelajari; 3). proses pengajaran menjadi lebih menarik; 4). siswa dirangsang untuk aktif mengamati, menyesuaikan antara teori dan kenyataan, dan mencoba melakukannya sendiri.

Disamping memiliki kelebihan, metode demonstrasi juga memiliki kekurangan, antara lain: 1). metode ini memerlukan keterampilan guru secara khusus, karena tanpa ditunjang dengan hal itu, pelaksanaan demonstrasi akan tidak efektif; 2). fasilitas seperti peralatan, tempat, dan biaya yang memadai tidak selalu tersedia dengan baik; 3). demonstrasi memerlukan kesiapan dan perencanaan yang matang disamping memerlukan waktu yang cukup panjang, yang mungkin terpaksa mengambil waktu atau jam mata pelajaran lain.

Simulasi berasal dari kata simulate yang artinya berpura-pura atau berbuat seolah-olah. Kata simulation artinya tiruan atau perbuatan yang pura-pura. Dengan demikian simulasi dalam metode mengajar dimaksudkan sebagai cara untuk menjelaskan sesuatu (bahan pelajaran) melalui perbuatan yang bersifat pura-pura atau melalui proses tingkah laku imitasi, atau bermain peran mengenai suatu tingkah laku yang dilakukan seolah-olah dalam keadaan yang sebenarnya (Sudjana, 1996).

Simulasi adalah metode dinamika yang menggambarkan atau mengungkapkan sistem fisik (non manusia) atau sosial (manusia) yang diabstraksikan dari kenyataan dan disederhanakan untuk proses belajar. Unsur penting dalam simulasi adalah abstraksi dari kenyataan yang ada, dan abstraksi itu diperankan (Greenblat dalam Suparno, 2006). 
Ada beberapa langkah yang perlu diperhatikan dalam menyiapkan simulasi yaitu: a). orientasi, dalam langkah ini guru menjelaskan kepada siswa arti simulasi yang akan dilakukan, dengan demikian, siswa akan terarah dalam melakukan simulasi; b). persiapan peserta, guru perlu mempersiapkan skenario simulasi dan persoalan yang ingin disimulasikan, perlu pengaturan tempat dan suasana serta penunjukkan peran pada tiap-tiap siswa; c). perjalanan simulasi, langkah berikutnya siswa melakukan simulasi secara aktif, guru memfasilitasi agar simulasi berjalan lancar dan meriah, setelah melakukan simulasi perlu penutupan; d). diskusi, pada akhir simulasi guru mengajak berdiskusi sebentar tentang simulasi yang baru dilakukan, mengadakan refleksi yang terjadi dalam simulasi.

Keuntungan dan kegunaan simulasi antara lain: akan tercipta pembelajaran yang menyenangkan (joyfull learning). Siswa tertarik dan senang belajar, siswa sungguh menghayati peran yang dilakukan dan pengetahuan mereka menjadi lebih realistik, lebih menunjukkan pembelajaran konstruktivisme, siswa sungguh aktif berfikir, kreatif, dan berpartisipasi dalam belajar.

Keberhasilan belajar IPA juga tidak terlepas dari kemampuan individu yang dimiliki siswa, salah satu faktor internal, yaitu kecerdasan siswa. Armstrong (2002), kecerdasan adalah kemampuan untuk menangkap situasi baru serta kemampuan untuk belajar dari pengalaman masa lalu seseorang. Setiap individu memiliki sembilan (9) jenis kecerdasan yang berbeda-beda dan menggunakannya dengan cara-cara yang sangat personal. Pembatasan pada program pendidikan yang hanya memfokuskan diri pada kecerdasan linguistik dan matematis, telah meminimalisis arti penting bentuk-bentuk potensi lain yang dimiliki individu (Gardner, dalam Prasetyaningrum, 2003).

Salah satu kecerdasan yang menjadi tinjauan dalam penelitian ini adalah kecerdasan spasial, yaitu kemampuan individu untuk menyerap, mengubah, dan menciptakan kembali berbagai macam aspek dunia visualspasial serta dengan mudah menyesuaikan orientasi dalam berpikir tiga dimensi.

Orang dengan kecerdasan spasial memiliki kemampuan dalam menggambar. Kelebihan para pemilik picture smart ini, selain terletak pada imajinasinya juga pada matanya. Mata mereka biasanya peka atau jeli menangkap hal-hal yang tidak dilihat oleh orang lain. Adapun tes kemampuan ini memiliki 5 jenis soal yaitu: 1). permainan warna; 2). hubungan gambar; 3). pengelompokkan gambar; 4). bayangan gambar; dan 5). identifikasi gambar. (Carter, 2011). Siswa yang dengan mudah mengingat gambar, dan memiliki imajinasi yang kuat, maka dikategorikan dalam kecerdasan spasial tinggi. Sebaliknya siswa yang lemah dalam menyelesaikan serangkaian tes kecerdasan spasial dikategorikan siswa yang kecerdasan spasialnya rendah.

Kemampuan berinteraksi akan sangat mempengaruhi hasil belajar siswa, karena dengan berinteraksi seorang siswa akan saling bertukar pengalaman. Bertukar pengalaman yang dimaksud adalah bertukar ilmu pengetahuan yang dimiliki oleh masing-masing siswa. Vygotsky dalam Santrock (2008), menegaskan bahwa secara aktif anak-anak menyusun pengetahuan dan mengembangkan konsep-konsep mereka secara sistematis, logis dan rasional yang diperoleh dari koneksikoneksi sosial dengan orang lain yang kompeten.

Soekanto (2007), menjelaskan bentuk interaksi sosial yang berkaitan dengan proses asosiatif dapat terbagi atas bentuk kerja sama (cooperation), akomodasi (accomodation), dan asimilasi (assimilation), sedangkan bentuk interaksi sosial yang berkaitan dengan proses disosiatif ini dapat terbagi atas bentuk persaingan (competition) dan pertentangan (conflict). Siswa dengan interaksi sosial tinggi cenderung memperoleh prestasi belajar tinggi, demikian sebaliknya, siswa yang mempunyai interaksi sosial rendah akan cenderung mempunyai prestasi belajar rendah.

Interaksi sosial anak dengan orang dewasa yang lebih terampil dan teman sebaya, akan meningkatkan perkembangan kognitifnya. Melalui interaksi ini siswa yang kurang terampil dapat belajar dari anggota siswa lain untuk beradaptasi dan berhasil di masyarakat yang lebih luas. Suprijono (2011), menyatakan interaksi sosial merupakan dialog interaktif sebagai kunci dari semua kehidupan sosial. Jadi, tanpa interaksi sosial tidak mungkin ada kehidupan bersama dan tidak ada pengetahuan yang disebut Piaget sebagai pengetahuan sosial. 


\section{Metode Peneltian}

Populasi dalam penelitian ini adalah seluruh siswa kelas V Madrasah Ibtidaiyah di Kecamatan Mantingan tahun pelajaran 2012/2013 yang terdiri dari 6 Madrasah. Teknik pengambilan sampel dalam penelitian ini menggunakan teknik Cluster Random Sampling, 2 Madrasah terpilih sebagai kelas eksperimen. Kelas eksperimen I adalah MIN Pakah diberi pembelajaran dengan metode demonstrasi dan kelas eksperimen II adalah MI Awaliyah Kedungharjo diberi pembelajaran dengan metode simulasi. Desain penelitian yang digunakan adalah penelitian eksperimen (experimental research) yang berusaha untuk mengetahui pengaruh antara suatu variabel terhadap variabel lainnya dengan rancangan penelitian disajikan dalam desain faktorial $2 \times 2 \times 2$ dengan teknik analisis varians.

Instrumen yang digunakan berupa silabus, RPP, LKS dan instrumen pengambilan data berupa tes, angket dan lembar pengamatan. Instrumen bentuk tes untuk mengukur prestasi kognitif dan tingkat kecerdasan spasial siswa dengan menggunakan tes pilihan ganda dengan satu jawaban benar. Angket untuk mengukur tingkat interaksi sosial siswa yang dilaksanakn sebelum kegiatan belajar mengajar berlangsung. Penilaian prestasi belajar afektif dan psikomotorik menggunakan angket tanggapan siswa yang dilakukan setelah pembelajaran, sedangkan lembar pengamatan digunakan untuk mengukur prestasi belajar afektif dan psikomotorik pada saat pembelajaran berlangsung. Dokumentasi berupa rekapitulasi nilai UAS semester 2 kelas IV, digunakan untuk menguji kesetaraan sampel dan foto kegiatan siswa pada saat pelaksanaan pembelajaran. Uji validitas isi instrumen dilakukan oleh tim ahli sebelum diujicobakan.

Setelah diujicobakan maka instrumen tes prestasi kognitif dan kecerdasan spasial diuji reliabilitas, tingkat kesukaran. dan uji daya beda. Untuk interaksi sosial siswa dilakukan uji reliabilitas instrumen. Setelah dihitung menggunakan program anates diperoleh; 30 butir soal terdapat kualifikasi butir soal sulit 2, kualifikasi sedang ada 21 butir dan kualifikasi mudah ada 7 butir, dengan reliabilitas tes 0,74 . 25 soal kecerdasan spasial didapatkan 25 butir soal pilihan ganda menunjukkan bahwa terdapat kualifikasi butir soal sulit 1 butir, kualifikasi sedang ada 12 butir, soal dengan kualifikasi mudah ada 12 butir, dengan reliabilitas tes 0,82 . Sedangkan 40 butir angket interaksi sosial siswa reliabilitas tes rata-rata 0,76 . Uji prasyarat analisis dilakukan melalui uji normalitas dan homogenitas dilakukan menggunakan rumus Kolmogorov-Smirnov dan Levene's Tes. Data prestasi belajar yang diperoleh dianalisis dengan menggunakan analisis variansi tiga jalan (uji anava).

\section{Hasil Penelitian dan Pembahasan}

Data penelitian diuji hipotesis melalui anava tiga jalan menggunakan program SPSS 18 (Tabel 1).

Tabel 1. Hasil Uji anava prestasi belajar kognitif, afektif, dan psikomotorik.

\begin{tabular}{|c|c|c|c|c|}
\hline \multirow{2}{*}{ No. } & \multirow{2}{*}{ Analisis } & \multicolumn{3}{|c|}{ p-value } \\
\hline & & Kognitif & Afektif & Psiko \\
\hline 1 & Metode & $0,003^{*}$ & $0,003 *$ & $0,007 *$ \\
\hline 2 & KS & $0,000^{*}$ & $0,000^{*}$ & $0,002 *$ \\
\hline 3 & IS & 0,132 & 0,366 & $0,000^{*}$ \\
\hline 4 & Metode* ${ }^{*} S$ & 0,328 & 0,700 & $0,018 *$ \\
\hline 5 & Metode*IS & $0,023^{*}$ & 0,245 & 0,366 \\
\hline 6 & $\mathrm{KS} * \mathrm{IS}$ & 0,951 & $0,025^{*}$ & 0,372 \\
\hline 7 & $\begin{array}{l}\text { Metode*KS } \\
\text { *IS }\end{array}$ & 0,299 & 0,526 & $0,044^{*}$ \\
\hline
\end{tabular}

Ket : *) signifikan pada uji alternatif anava dengan $\alpha=0,05$.

1. Pengaruh pembelajaran kontekstual melalui metode demonstrasi dan simulasi terhadap prestasi belajar.

Hasil uji anava diperoleh prestasi belajar kognitif, afektif, dan psikomotorik dengan nilai $p$-value $<0,05$, berarti terdapat pengaruh pembelajaran kontekstual melalui metode demonstrasi dan simulasi terhadap prestasi belajar kognitif, afektif, dan psikomotorik. Metode simulasi dinilai lebih efektif dari pada metode demonstrasi sebab memberikan hasil rerata lebih tinggi pada semua prestasi belajar. (Tabel 2).

Tabel 2. Prestasi belajar siswa ditinjau dari pengaruh \begin{tabular}{lccc}
\multicolumn{4}{c}{ metode pembelajaran } \\
& Kognitif & Afektif & Psiko \\
\hline Metode demonstrasi & 60 & 75 & 76 \\
Metode simulasi & 68 & 79 & 80 \\
\hline
\end{tabular} Kondisi Madrasah di Kecamatan Mantingan memiliki kondisi sarana dan prasarana belajar yang kurang mendukung, serta terletak pada wilayah pedesaan, sangat cocok diterapkan pembelajaran dengan pendekatan kontekstual, karena dapat membantu guru menghadirkan dunia nyata ke dalam kelas dan mendorong siswa membuat 
hubungan antara pengetahuan yang dimilikinya dengan menerapkannya dalam kehidupan mereka sehari-hari, mengkonstruksi sendiri, bekal untuk memecahkan masalah dalam kehidupannya. Hal ini relevan dengan penelitian yang dilakukan Smith (2006).

Penggunaan metode pembelajaran bergantung pada pendekatan pembelajaran yang digunakan guru saat menyajikan materi pembelajaran. Untuk menyajikan pembelajaran yang efektif guru dapat menggunakan metode pembelajaran yang bervariasi, seperti demonstrasi dan simulasi. Metode demonstrasi dapat dilakukan dengan menunjukkan benda baik yang sebenarnya, model, maupun tiruannya dan disertai dengan penjelasan lisan. Sedangkan metode simulasi merupakan cara untuk menjelaskan sesuatu (bahan pelajaran) melalui perbuatan yang bersifat pura-pura atau melalui proses tingkah laku imitasi, atau bermain peran mengenai suatu tingkah laku yang dilakukan seolah-olah dalam keadaan yang sebenarnya (Hartini, 2010).

Keuntungan metode simulasi antara lain: akan tercipta pembelajaran yang menyenangkan (joyfull learning) dan memotivasi belajar siswa. Siswa tertarik dan senang belajar, dan sambil bermain peran. Siswa sungguh menghayati peran yang dilakukan dan pengetahuan mereka menjadi lebih realistik, pada tahap ini karakteristik siswa juga perlu diperhatikan, sebab dalam tahap perkembangan kognitifnya siswa pada pendidikan dasar dalam tahap operasional konkret, sehingga diperlukan metode pembelajaran yang dapat mengkonkretkan materi dan membantu siswa dalam memecahkan masalahnya.

Hasil penelitian ini merupakan penguatan aplikasi penelitian dari Sarwanto (2007), bahwa melalui metode simulasi dapat mengkonkretkan peristiwa yang kasad mata maupun abstrak dengan peragaan fisik. Metode simulasi bermain peran dapat diaplikasikan pada pembelajaran konsep gerak rotasi, revolusi bumi dan bulan, simulasi dalam pembelajaran rantai karbon serta simulasi pada konsep aliran darah (dalam biologi). Senada dengan Hastuti (2007), belajar konsep sistem peredaran darah manusia dengan metode simulasi lebih efektif dalam meningkatkan hasil belajar dan keaktifan siswa dibandingkan dengan pembelajaran yang menggunakan metode ceramah.
2. Pengaruh kecerdasan spasial tinggi dan rendah terhadap prestasi belajar.

Hasil uji anava menerangkan terdapat pengaruh kecerdasan spasial tinggi dan rendah terhadap prestasi belajar kognitif, afektif dan psikomotorik. Siswa yang memiliki kecerdasan spasial tinggi memperoleh rerata prestasi belajar lebih baik yaitu kognitif sebesar 73, afektif sebesar 84, dan psikomotorik sebesar 82 (Tabel 3).

Tabel 3. Prestasi belajar siswa ditinjau dari pengaruh kecerdasan spasial

\begin{tabular}{cccc}
\hline & Kognitif & Afektif & Psikomotor \\
\hline KS tinggi & 73 & 84 & 82 \\
KS rendah & 56 & 70 & 74 \\
\hline
\end{tabular}

Kecerdasan adalah kemampuan psikofisik untuk mereaksikan rangsangan atau menyesuaikan diri dengan lingkungan dengan cara yang tepat. Kemampuan dasar yang tinggi pada siswa, memungkinkan anak dapat menggunakan pikirannya untuk belajar dan memecahkan pesoalan-persoalan baru secara tepat, cepat dan, berhasil. Sebaliknya tingkat kemampuan dasar yang rendah dapat mengakibatkan siswa mengalami kesulitan dalam belajar. Spatial Intelligence (kecerdasan spasial), yaitu kemampuan individu untuk menyerap, mengubah, dan menciptakan kembali berbagai macam aspek dunia visualspasial serta dengan mudah menyesuaikan orientasi dalam berpikir tiga dimensi. Kemampuan siswa yang dimiliki seyogyanya dapat membantu siswa mempelajari konsep sistem peredaran darah manusia, yang diketahui memerlukan kecerdasan keruangan yang tinggi, senada dengan pendapat Gardner dalam Hartini (2010), bahwa peserta didik ternyata lebih mudah belajar atau menangkap bahan yang diajarkan pendidik apabila bahan itu disajikan sesuai dengan kecerdasan peserta didik yang menonjol.

Siswa yang memiliki kecerdasan spasial tinggi mampu memperoleh prestasi belajar lebih baik dibanding dengan siswa yang memiliki kecerdasan spasial rendah, Hasil penelitian ini didukung Junita (2009), menyatakan siswa yang memiliki kecerdasan visual-spasial tinggi dan rendah memiliki perbedaan hasil belajar. Siswa yang memiliki kecerdasan visual-spasial tinggi, maka siswa tersebut mampu menerima informasi yang dilihatnya dan memproses informasi tersebut dengan baik dan memiliki pemikiran yang prosesnya cepat dan motoriknya juga aktif, 
sehingga memperoleh perestasi belajar lebih baik. Sebaliknya siswa yang memiliki kecerdasan visual-spasial rendah, maka siswa tersebut cenderung berfikir lambat dan motoriknya cenderung pasif sehingga akan mengalami kesulitan dalam belajarnya.

3. Pengaruh interaksi sosial (IS) tinggi dan rendah terhadap prestasi belajar.

Hasil uji anava, menyebutkan bahwa terdapat pengaruh antara interaksi sosial tinggi dan rendah terhadap prestasi belajar psikomotorik tetapi tidak terdapat pengaruh terhadap prestasi belajar kognitif dan afektif. Siswa yang memiliki interaksi sosail tinggi memperoleh rerata prestasi belajar lebih baik yaitu kognitif sebesar 68, afektif sebesar 79 dan psikomotorik sebesar 84 (Tabel 4).

Tabel 4. Prestasi Belajar siswa ditinjau dari pengaruh \begin{tabular}{lccc}
\multicolumn{3}{c}{ interaksi sosial } & \\
\hline & Kognitif & Afektif & Psiko \\
\hline IS Tinggi & 68 & 79 & 84 \\
IS Rendah & 61 & 75 & 73 \\
\hline
\end{tabular}

Interaksi sosial memberikan peran dalam prestasi belajar siswa. Siswa yang memiliki interaksi sosial tinggi akan lebih mudah memecahkan masalah dalam proses belajarnya, melalui bentuk berkomunikasi dengan guru, siswa dengan siswa dan siswa dengan linkungannya. Menurut Soekanto (2007), menyatakan bahwa interaksi sosial merupakan hubungan-hubungan sosial yang dinamis yang menyangkut antara orang-perorangan, antar kelompok-kelompok manusia, maupun antara orang-perorangan dengan kelompok manusia.

Prestasi psikomotorik berkaitan erat dengan keterampilan proses sains yang didalamnya mengandung kegiatan-kegiatan yang memerlukan komunikasi siswa dengan siswa dan siswa dengan guru, baik perorangan maupun dalam kelompok. Hal ini senada oleh Suprijono (2011), interaksi sosial merupakan dialog interaktif sebagai kunci dari semua kehidupan sosial. Jadi, tanpa interaksi sosial tidak mungkin ada kehidupan bersama dan tidak ada pengetahuan yang disebut Piaget sebagai pengetahuan sosial. Oleh karena itu siswa yang memiliki interaksi sosial baik berdampak baik pula pada prestasi belajar aspek psikomotoriknya.

Hasil penelitian ini didukung oleh Jailani (2008), dalam jurnalnya menurut pandangan konstruktivis dalam proses pembelajaran IPA seyogyanya disediakan serangkaian pengalaman berupa kegiatan nyata yang rasional atau dapat dimengerti siswa dan memungkinkan terjadi interaksi sosial. Dengan kata lain siswa harus terlibat secara langsung dalam kegiatan nyata.

4. Pengaruh interaksi antara metode demonstrasi dan simulasi dengan kecerdasan spasial terhadap prestasi belajar.

Dari uji anava diperoleh nilai p-value < 0,05 pada prestasi belajar psikomotorik, sementara itu diperoleh p-value > 0,05 pada prestasi belajar kognitif dan afektif. Data tersebut menggambarkan bahwa terdapat pengaruh interaksi antara penerapan pendekatan kontekstual melalui metode demonstrasi dan simulasi dengan kecerdasan spasial terhadap prestasi belajar aspek psikomotorik, tidak ada pengaruh interaksi terhadap prestasi aspek kognitif dan afektif. Siswa yang belajar dengan metode simulasi dan memiliki kecerdasan spasial tinggi memperoleh prestasi belajar lebih baik yaitu kognitif sebesar 78, afektif sebesar 89 dan psikomotorik sebesar 89 (Tabel. 5).

Tabel 5. Prestasi belajar siswa ditinjau dari pengaruh interaksi antara metode dengan kecerdasan spasial

\begin{tabular}{lcccc}
\hline \multirow{2}{*}{ Metode } & Kecerdasan & \multicolumn{3}{c}{ Rerata } \\
\cline { 3 - 5 } & Spasial & Kog & Afek & Psiko \\
\hline \multirow{2}{*}{ Demonstrasi } & Tinggi & 69 & 81 & 76 \\
& Rendah & 49 & 67 & 75 \\
\multirow{2}{*}{ Simulasi } & Tinggi & 78 & 89 & 89 \\
& Rendah & 60 & 72 & 73 \\
\hline
\end{tabular}

Pembelajaran kontekstual memusatkan pada peserta didik mengerti makna dari yang mereka pelajari, manfaatnya, status mereka, tercapainya dan proses belajar yang telah mereka pelajari. Dalam proses belajar tersebut siswa dituntut aktif dan guru berperan sebagai fasilitator. Sudjana (1996), menyatakan upaya untuk membangkitkan atau motivasi belajar siswa yaitu menggunakan cara atau model dan media mengajar yang bervariasi, karena dengan pendekatan dan media yang bervariasi kebosanan siswa dapat dihalangi. Hasil penelitian ini didukung oleh Elliot dalam Sulistyowati (2010), menyatakan metode pengajaran yang memasukkan berfikir spasial seperti bentuk-bentuk balok yang menghubungkan konsep spasial dapat membantu terhadap pemecahan masalah dalam dunia anak-anak.

Senada dengan Setyowati (2009), menyatakan dengan metode CIRC hasil belajar peserta didik verbal-linguistik lebih tinggi daripada peserta didik matematis-logis dan 
kinestetik-badani. Baik pada perhitungan nilai rata-rata maupun pada uji beda rata-rata, sehingga dapat diartikan bahwa metode CIRC lebih sesuai untuk peserta didik dengan kecerdasan verbal-linguistik. Relevansi dari penelitiaan ini untuk melanjutkan penelitian baru menggunakan kecerdasan yang lain dari sembilan kecerdasan yang disampaikan oleh Gadner, pada penelitian ini metode simulasi lebih sesuai untuk siswa dengan kecerdasan spasial tinggi dalam pembelajaran IPA pada materi sistem peredaran darah manusia.

Hastuti (2007), menyatakan peredaran darah manusia kelas VIII semester II SMP N 1 Dukuhturi Tegal dengan metode simulasi lebih efektif dalam meningkatkan hasil belajar dan keaktifan siswa dibandingkan dengan pembelajaran menggunakan metode ceramah.

Blanchard dalam Suprijono (2011), membandingkan pola pembelajaran tradisional dan kontekstual. Pendekatan kontekstual menyandarkan pada memori spasial. Kecerdasan spasial siswa yang tinggi juga memberikan dampak positif terhadap prestasi belajar IPA pada meteri pokok sistem peredaran darah, karena pada konsep sistem peredaran darah mempelajari berbagai ruang jantung beserta fungsinya, jika siswa memiliki dasar kemampuan memvisualisasikan ruang jantung beserta fungsinya, maka siswa akan lebih mudah memahami cara kerja jantung dan lebih aktif dan menyenangkan dalam mengikuti pelajaran, maka akan berdampak pada prestasi belajar yang lebih baik. Siswa yang memiliki kecerdasan spasial tinggi dan diterapkan metode simulasi memberikan hasil prestasi belajar psikomotorik lebih baik.

5. Pengaruh interaksi antara metode demonstrasi dan simulasi dengan interaksi sosial siswa terhadap prestasi belajar.

Hasil uji anava, p-value $<0,05$ terjadi pada prestasi belajar kognitif, sementara itu pvalue $>0,05$ diperoleh pada prestasi belajar afektif dan psikomotorik. Data tersebut menggambarkan bahwa terdapat pengaruh interaksi antara pendekatan kontekstual melalui metode demonstrasi dan simulasi dengan kemampuan IS siswa terhadap prestasi belajar kognitif, dan tidak ada pengaruh interaksi terhadap prestasi afektif dan psikomotorik. Prestasi belajar siswa yang diberi pembelajaran dengan metode simulasi dengan interaksi sosial tinggi lebih baik daripada kelompok metode demonstrasi yaitu kognitif sebesar 79, afektif sebesar 85, psikomotorik sebesar 88 (Tabel 6).

Tabel 6. Prestasi Belajar ditinjau dari pengaruh interaksi

\begin{tabular}{ccccc}
\multicolumn{3}{c}{ antara metode dengan interaksi Sosial } \\
\cline { 3 - 5 } Metode & Interaksi & \multicolumn{3}{c}{ Rerata } \\
& Sosial & Kog & Afek & Psiko \\
\hline \multirow{2}{*}{ Demonstrasi } & Tinggi & 58 & 73 & 79 \\
& Rendah & 62 & 76 & 72 \\
\multirow{2}{*}{ Simulasi } & Tinggi & 79 & 85 & 88 \\
& Rendah & 60 & 74 & 73 \\
\hline
\end{tabular}

Pengetahuan tidak dihasilkan dari dalam diri individu, melainkan dibangun melalui interaksi dengan orang lain dan benda budaya, seperti buku. Hal ini menunjukkan bahwa pemahaman dapat ditingkatkan melalui interaksi dengan orang lain dalam aktivitas yang kooperatif (Santrock, 2008). Dalam hal ini pengaruh interaksi antara metode simulasi dan interaksi sosial kategori tinggi memberikan pengaruh yang positif, karena siswa yang diberi perlakuan tersebut berperan aktif dan mampu berinteraksi sosial dengan baik, siswa dengan guru ataupun siswa dengan teman, bahkan dengan teman yang sudah tahu, ataupun dengan yang belum tahu, dituntut menjadi tahu akibat adanya interaksi sosial dalam suasana belajar bersama. Lebih lanjut Vygotsky dalam Santrock (2008), menyatakan orang lain dan bahasa, memegang peranan penting dalam perkembangan kognitif anak. Interaksi sosial anak dengan orang dewasa yang lebih terampil dan teman sebaya, akan meningkatkan perkembangan kognitifnya.

Sedangkan siswa yang diberi metode demonstrasi menunjukkan siswa kurang aktif dalam mengikuti proses belajar, siswa cenderung belajar secara individual. Interaksi sosial tinggi yang dimiliki siswa dengan metode demonstrasi tidak begitu muncul pada saat kegiatan belajar mengajar berlangsung, bahkan siswa yang memiliki interaksi sosial rendah mampu memperoleh rerata prestasi belajar lebih tinggi dibanding dengan siswa yang memiliki interaksi sosial tinggi, biasanya siswa yang lebih tahu cenderung memiliki sikap yang individualistik. Hal ini sesuai dengan pendapat Hartini (2010), bahwa situasi mental siswa untuk menghadapi pelajaran akan mempengaruhi perhatian dan ketekunan siswa selama proses siswa belajar.

6. Pengaruh interaksi antara kecerdasan spasial dengan interaksi sosial siswa terhadap prestasi belajar

Hasil uji anava menggambarkan bahwa 
terdapat pengaruh interaksi antara kecerdasan spasial dengan interaksi sosial siswa terhadap prestasi belajar afektif tetapi tidak terdapat pengaruh interaksi terhadap prestasi belajar kognitif dan psikomotorik. Siswa dengan kecerdasan spasial dan interaksi sosial tinggi memperoleh prestasi belajar terbaik yaitu kognitif sebesar 85, afektif sebesar 76, dan psikomotorik sebesar 88 (Tabel. 7).

Tabel 7. Prestasi Belajar ditinjau dari pengaruh Interaksi antara kecerdasan spasial \& interaksi sosial

\begin{tabular}{ccccc}
\hline \multirow{3}{*}{$\begin{array}{c}\text { Kecerdasan } \\
\text { Spasial }\end{array}$} & Interaksi & \multicolumn{3}{c}{ Rerata } \\
\cline { 3 - 5 } Tinggi & Sosial & Kog & Afek & Psiko \\
& Tinggi & 76 & 84 & 88 \\
\multirow{2}{*}{ Rendah } & Rendah & 69 & 85 & 75 \\
& Tinggi & 57 & 74 & 78 \\
& Rendah & 55 & 68 & 71 \\
\hline
\end{tabular}

Konsep sistem peredaran darah manusia merupakan materi yang penting, yang bersifat konkret namun tidak bisa diamati secara langsung, untuk itu memungkinkan siswa untuk belajar melalui gambar atau membuat tiruan objek yang terjadi saat proses pembelajaran, akan ditangkap siswa dengan mudah apabila siswa memiliki kecerdasan spasial tinggi, untuk merealisasikan pembelajaran yang bermakna dari pengalaman masing-masing yang dikonstruk oleh siswa. Maka tak dipungkiri perlu adanya aktivitas antar individu, misalnya siswa saling menegur, berjabat tangan, saling berbicara dan saling kontak fisik. Aktivitas-aktivitas tersebut itu merupakan bentuk interaksi sosial. Soekanto (2007), menyatakan bahwa interaksi sosial merupakan hubungan-hubungan sosial yang dinamis yang menyangkut antara orangperorangan, antar kelompok-kelompok manusia, maupun antara orang-perorangan dengan kelompok manusia. Dalam Taksonomi Bloom, kawasan afektif (affective domain) perilaku yang dimunculkan seseorang sebagai pertanda cenderuang untuk membuat pilihan atau keputusan untuk beraksi didalam lingkungan lingkungan tertentu, tujuan belajar berkenaan dengan minat, sikap dan nilai serta pengembangan penghargaan dan penyesuaian diri.

7. Pengaruh interaksi antara pendekatan kontekstual melalui metode demonstrasi dan simulasi, kecerdasan spasial, dan interaksi sosial siswa terhadap prestasi belajar.

Hasil uji anava menggambarkan bahwa terdapat pengaruh interaksi antara metode demonstrasi dan simulasi, kecerdasan spasial, dan interaksi sosial terhadap prestasi belajar psikomotorik tetapi tidak terdapat pengaruh interaksi terhadap prestasi belajar kognitif dan afektif. Siswa yang diberi pembelajaran dengan metode simulasi dengan kecerdasaan spasial dan interaksi sosial tinggi memperoleh prestasi belajar terbaik yaitu prestasi belajar kognitif sebesar 82, afektif sebesar 89, dan psikomotorik sebesar 91 (Tabel 8).

Tabel 8. Prestasi belajar ditinjau dari pengaruh interaksi antara metode, kecerdasan spasial, dan interaksi sosial

\begin{tabular}{|c|c|c|c|c|c|}
\hline Metode & $\mathbf{K S}$ & IS & Kog & Afek & Psiko \\
\hline \multirow{4}{*}{$\begin{array}{l}\text { Demon } \\
\text { strasi }\end{array}$} & \multirow{2}{*}{ Tinggi } & Tinggi & 69 & 76 & 83 \\
\hline & & Rendah & 68 & 84 & 76 \\
\hline & \multirow{2}{*}{ Rendah } & Tinggi & 46 & 70 & 70 \\
\hline & & Rendah & 53 & 64 & 75 \\
\hline \multirow[t]{4}{*}{ Simulasi } & \multirow{2}{*}{ Tinggi } & Tinggi & 82 & 89 & 91 \\
\hline & & Rendah & 72 & 88 & 82 \\
\hline & \multirow{2}{*}{ Rendah } & Tinggi & 74 & 78 & 83 \\
\hline & & Rendah & 56 & 69 & 69 \\
\hline
\end{tabular}

Pendekatan kontekstual pada prinsipnya membantu guru untuk mengorganisasikan pengalaman belajar untuk mencapai tujuan. Pengalaman belajar yang dimiliki siswa lebih bermakna melalui sebuah metode pembelajaran yang sesuai dengan karakteristik mata pelajaran serta kondisi siswa. Siswa yang belajar dengan metode simulasi lebih aktif, banyak melakukan aktifitas belajar, seperti melakukan simulasi main peran, sebab tidak hanya mendengarkan penjelasan dari guru, siswa belajar melalui skenario simulasi yang telah disediakan. Siswa yang memiliki kecerdasan spasial tinggi sangat mudah mengingat gambar dalam penelitian ini gambar sistem peredaran darah manusia, serta mudah mengingat skenario simulasi akan yang diperankan, untuk itu Elliot dalam Sulistyowati (2010), menyatakan metode pengajaran yang memasukkan berfikir spasial seperti bentukbentuk balok yang menghubungkan konsep spasial dapat membantu terhadap pemecahan masalah dalam dunia anak-anak.

Kemampuan memecahkan masalah tidak hanya berkaitan dengan berhasil dan tidaknya menghitung perkalian saja, namun juga meliputi kemampuan membentuk suatu team, kemampuan untuk mengatur anggota dalam kelompok supaya belajar lebih bermakna dan menyenangkan, pada tahap inilah interaksi sosial berlangsung dalam proses belajar. Siswa yang memiliki interaksi sosial tinggi akan lebih mudah berkomunikasi dengan guru, dengan teman, baik dengan teman yang belum tahu maupun dengan teman yang belum tahu, disinilah interaksi sosial dapat mempengaruhi 
prestasi belajar seseorang khususnya pada prestasi belajar psikomotorik.

\section{Kesimpulan dan Saran}

Hasil penelitian ini dapat disimpulkan bahwa: 1). terdapat pengaruh metode demonstrasi dan simulasi terhadap prestasi belajar; 2). terdapat pengaruh kecerdasan spasial kategori tinggi dan rendah terhadap prestasi belajar kognitif, afektif dan psikomotorik; 3). terdapat pengaruh interaksi sosial berkategori tinggi dan rendah terhadap prestasi belajar psikomotorik tetapi tidak terdapat pengaruh terhadap prestasi kognitif dan afektif; 4). terdapat pengaruh interaksi antara metode demonstrasi dan simulasi dengan kecerdasan spasial siswa terhadap prestasi belajar psikomotorik tetapi tidak terdapat pengaruh terhadap prestasi belajar kognitif dan afektif; 5). terdapat pengaruh interaksi antara metode demonstrasi dan simulasi dengan interaksi sosial siswa terhadap prestasi belajar aspek kognitif tetapi tidak terdapat pengaruh terhadap prestasi belajar afektif dan psikomotorik. 6). terdapat pengaruh interaksi antara kecerdasan spasial dengan interaksi sosial siswa terhadap prestasi belajar afektif tetapi tidak terdapat pengaruh terhadap prestasi belajar kognitif dan psikomotorik; 7). terdapat pengaruh interaksi antara metode demonstrasi dan simulasi, kecerdasan spasial, dan interaksi sosial siswa terhadap prestasi belajar psikomotorik tetapi tidak terdapat pengaruh terhadap prestasi aspek kognitif dan afektif.

Berdasarkan dari data penelitian, maka disarankan bagi peneliti selanjutnya mengembangkan penelitian tentang pendekatan kontekstual melalui metode pembelajaran yang lebih variasi dalam meningkatkan prestasi belajar. Pembelajaran IPA khususnya materi sistem peredaran darah manusia dengan pendekatan kontekstual, agar pelaksanaanya lebih efektif perlu memperhatikan hal-hal sebagai berikut: 1). pemilihan metode pembelajaran perlu disesuaikan dengan materi yang akan diajarkan, supaya siswa dapat menjadi lebih aktif, kreatif dan menyenangkan, serta memiliki motivasi belajar yang tinggi; 2). tahap perkembangan kognitif siswa perlu diperhatikan, siswa SD/MI termasuk dalam kategori operasional berfikir konkret, sehingga dalam penelitian ini diharapkan melalui pembelajaran kontekstual, siswa dihadapkan pada kondisi pembelajaran nyata pada materi pokok sistem peredaran darah manusia melalui metode demonstrasi dan simulasi; 3). pendidik sebaiknya lebih sering memberikan latihanlatihan atau tugas yang dapat melatih kecerdasan spasial siswa karena hal itu menjadi dasar pemikiran kreatif siswa; 4). pendidik sebaiknya melakukan penilaian melalui lembar observasi atau melalui angket untuk mengetahui tingkat interaksi sosial siswa, sehingga dapat dijadikan dasar dalam menentukan komposisi keanggotaan kelompok belajar yang heterogen.

\section{DAFTAR PUSTAKA}

Armstrong, (2002). Sekolah Para Juara: Menerapkan Multiple Intelegences diDunia Pendidikan. Bandung. Kaifa.

BSNP. (2008). Standar Isi Mata Pelajaran Ilmu Pengetahuan Alam Kurikulum Tingkat Satuan Pendidikan SD/MI. Jakarta: Pusat Kurikulum Balitbang Depdiknas.

Carter, P. (2011). Tes IQ Dan Tes Bakat. Menilai Kemampuan Penalaran Verbal, Numerik, dan Spasial Anda. Cetakan I. Jakarta: PT Indeks.

Elaine, B. J. (2011). CTL Contextual Teaching \& Learning Menjadikan Kegiatan Belajar Mengajar Mengaysikkan dan Bermakna. Jakarta. Kaifa.

Hartini, N. (2010). Teori Belajar dan Pembelajaran. Bogor. Ghalia Indonesia

Hastuti, R. P. (2007). Keefektifan Penerapan Metode Simulasi pada Konsep Peredaran Darah Manusia di Kelas VIII Semester II SMPN I Dukuhturi Tegal. Skripsi. FMIPA. UNNES. Semarang.

Jailani. (2008). Model Pembelajaran Sains Menurut Pandangan Kontruktivisme, Jurnal pendidikan Serambi Ilmu, 6 (1). 1-6.

Junita. (2009). Pengaruh Penggunaan Media Pembelajaran dan Kecerdasan Visual-Spasial Terhadap Hasil Belajar Keterampilan Komputer dan Pengelolaan Informasi Siswa SMKN 2 Rantau. Tesis. UNM. Medan.

Mulyasa, E. (2011). Menjadi Guru Profesional. Bandung. PT Remaja Roda Karya.

Prasetyaningrum, J. (2003). Psikologi Perkembangan Anak. Makalah, Intensive 
ISSN: 2252-7893, Vol 2, No 12013 (hal 76-87)

http://jurnal.fkip.uns.ac.id/index.php/sains

Practical Psychologi Course (IPPI). Jasa Psikologi Indonesia, Surakarta.

Santrock, J.W. (2008). Life-Span Development. Perkembangan Masa Hidup. (alih bahasa: Chusairi dan Damanik). Jakarta. Penerbit Erlangga.

Sarwanto. (2007). Ketrampilan Proses dalam Simulasi Main Peran. Jurnal Pendidikan MIPA, $8(1), 1-68$.

Setyowati, D. M. (2009). Penerapan Kecerdasan Majemuk Untuk Meningkatkan Hasil Belajar Fisika Peserta Didik. Jurnal Berkala Fisika Indonesia, 1 (2), 1-8.

Sudjana, N. (1996). Penilaian Hasil Proses Belajar Mengajar. Bandung. PT. Remaja Rosda Karya
Sulistyowati. (2010). Upaya Pengembangan Kecerdasan Visual-Spasial Anak Melalui Permainan Balok. Skripsi. UMS. Surakarta.

Suparno, P. (2006). Teori Perkembangan Kognitif Jean Piaget. Yogyakarta: Kanisius.

Suprijono, A. (2011). Cooperative Learning Teori dan Aplikasi Paikem. Yogyakarta. Pustaka Pelajar.

Soekanto, S. (2007). Sosiologi Suatu Pengantar. Jakarta. Raja Grafindo Persada.

Smith, B. P. (2006). Integrating Contextual Teaching and Learning Practices Into The Family and Consumer Sciences Teachers Curriculum. Journal of Family and Consumer Sciences Education, 24(1), 1-14.

Trianto. (2007). Model-Model Pembelajaran Inovatif Berorientasi Konstruktivistik. Jakarta. Prestasi Pustaka. 
JURNAL INKUIRI

ISSN: 2252-7893, Vol 2, No 12013 (hal 76-87)

http://jurnal.fkip.uns.ac.id/index.php/sains 